\title{
Language And Ecology In Silau Malela Society (Ecolinguistics Study)
}

\author{
Akmal \\ Ari Dermawan \\ Sekolah Tinggi Manajemen Informatika Komputer Royal. Kisaran. \\ Indonesia \\ akmal.shafa@gmail.com \\ Article History: Submitted on $15^{\text {th }}$ June 2021; Accepted on $2^{\text {nd }}$ November 2021; \\ Published on 30 th December 2021
}

\begin{abstract}
This study focused on to ecolinguistics study that talks about the language and ecology in the Silau Malela society. In this study was to find out how the people who lived in Silau Malela, merged into the environment to keep the balancing between human and their environment. Ecolinguistics is an interdisciplnary studies between ecology or environment and language (linguistics) which is expressed by the human. So this study was not focused on the ecology, but it discussed about the language in the life. This study used the qualitative research by doing observation and interview the people who lived in Silau Malela. This research describes about the relationship between human and environment communication. This society is so familiar to their environment and they also keep the situation so that they can communicate to the surrounding such as their cows, dogs, and other (the pets) and plantations when they do their activities with their pets and plantation. They also gave the name for their pets and sometimes to their plantation so that they understood the meaning of their owner when they were talking to their environment.
\end{abstract}

Keywords: ecology, language, ecolinguistics, society.

\section{INTRODUCTION}

If we talk about ecolinguistics, it auotomatically discussed about the interdisciplinary studies that focus on the relationship between the ecology study and the linguistics study. In the discussion and its nature involves the study of sociology, anthropology, psychology. In addition to the social aspects, ecolinguistics considers the ecological aspects of the language spoken by speakers in a society. Socioecological aspects greatly affect the maintenance, balance, and environmental inheritance of future generations. 
Ecolinguistics or language ecology, seeks to create a healthy environment, by incorporating local ecological wisdom into the language (A. F. Fill \& Penz, 2018; A. Fill \& Muhlhausler, 2001; Steffensen \& Fill, 2014; Yuniawan et al., 2017). So the same definition was said by Simanjuntak Tarida Alvina in her article that the ecolinguistics or language ecology found out to create a balacing environment, by showing the local wisdom into the language (the use in the environment) (Simanjuntak, 2019).

From the elaboration above, the ecolinguistics focused on the environment or the society either the animal, plantations, or human that were combined in the language which was used by the people as the members of society. The researcher was so interested to analyze the language and ecology were in the middle of Silau Malela people. They were able to communicate to their environment as they spoke to other people. Then the researcher wanted to find out how the people communicated to their environment. It was interesting gaps which the researcher found in this digital era or the technological development era. After that, the gap of this study is how are the language and ecology in the society of Silau Malela people?

The aims of this study, the researchers wanted to find out the Silau Malela society in communicating with their environment especially with their pets because most of people who lived there, had a few pets as their saving or richness when they needed to buy something or to pay something. The people who have the pets, could communicate to them and the pets were able to understand what the people expressed. So the researchers wanted to find out the communicatin was between the people who lived in Dusun II Silau Malela and their pets or plantations.

The relevant researchers were ECOLINGUISTIC "Water" in Toba Batak Language Community by Simanjuntak T.A. (2019)t . This study describes the fact that many natural ecolexics are not recognized anymore and even almost extinct in the Batak Toba community (rootlessness), some of which are mabakbak (flowing tears), bibis (flowing from a container fullness, lungkis (flowing smoothly) and then elaborated in the discussion (Simanjuntak, 2019). Language and Ecology in Ecolinguistics Perspective : A Case Study on Tunjuk Ajar Language in Riau, Indonesia by Jismulatif and Dahnilsyah (2019). The result of the research was that Tunjuk Ajar language practice in Melayu Riau society was formed by lexicon of flora and fauna such as the hutan, keladi, padi, laut, binatang, and itik. The meanings are closely related to the cultural values, and norms of the Riau society which reflect the interrelationship between the human beings and the nature (Jismulatif \& Dahnilsyah, 2019).

Language plus ecology $=$ language ecology. The first serious sociolinguistic tried to elaborate the language ecology pleaded for the linguistics to be grounded in the societal context and change. The ecological approach to language considered the complex web of the relationship that existed between the environment, language, and the speakers. The environment means that the physical, biological, and the social environment.(Skutnabb \& Kangas, 2011). 
Ecolinguistics is an umbrella term for the wide range of approaches, the linguistic (language) and the ecology as generally. The form of ecolinguistics analyses the language to reveal the stories we live by, the judges those stories from an ecological perspective, the resists damaging stories, and contributes to the search for new stories to live by (Chen, 2016; Stibbe, 2015).

Muhlhausler (1996:3) elaborated that there were four things which enabled the relationship between the language and the environment, such as: a) language is free and full of meaning; b) the language created by the world; c) the world is created by the language (the structuralist and post-structuralist view); d) the language is interconnected with the world (both of which are arranged and arranged but sometimes also free) (Muhlhausler, 2020). The four elements which had so close relationship between the language, the human and the environment, namely, the language functinos as a meaning, created by the environment or world, the world or environment was created by the language, and the language is a means of communications between the human and their environment. So it was so clear that the language can not be separated by their environment or society as the social creature.

The language and the environment had so closely relationship one another as the existence of a language that was influenced by the surrounding natural environment where the language was exploited by the human as the community. The development of language had been clearly observed with the emergence of linguists who had conducted to the numerous studies on the relationship between the language and the environment: the labeling of the objects or the animals which were correlated with the sounds produced by surrounding environment, such as the sounds of thunder, gurgling of water, and roars of animals (Crowley \& Bowern, 2010; A. Fill \& Muhlhausler, 2001; Jismulatif \& Dahnilsyah, 2019; Skutnabb \& Kangas, 2011; Yuniawan et al., 2017). In this explanations that the language and the environment were related to the human and the environment related to the animals and other objects surrounding the human life.

There are some study points for the language ecology, such as the comparative historical linguistics, the demographic linguistics, the sociolinguistics, the dialinguistics, dialectology, philology, the prescriptive linguistics, the glotopolytics, the ethnolinguistics, the anthropological linguistics or the cultural linguistics (cultural linguistics) typology. In other terms, it was also called as the language ecology. There were four terms which referred to it, they were the linguistic ecology, the ecological linguistics, the ecology of language / the language ecology, and ecolinguistics (Simanjuntak, 2019). From some points above, the ten points explained that they had so close relationship to the ecoloinguistics bacause they discussed about the environment and language or linguistics in the human life or the neighborhood. It can be seen the demographic, the historical, the sociology, the ethnology were about the environment and the history. Menawhile the dialectology, the perspective, the glotopology, the anthropology and cultural were still related to the human and the language as the speaker to 
communicate in their society.

Then there was the concentrartion of ecology. It was concerned in the phenomena which were as the following, namely: a) holistic (totality of relation), b) dynamic (the transformation produced by their struggle for existence), c) interactive (mutual relationships of all the organisms), and the last is the situated (the relations with the external world; organisms [...] in a single location (Garner, 2005; Steffensen \& Fill, 2014; Suryati et al., 2018). So the study was focused on the relationship between the human was as the user of language and the environment was as the creatures surrounding the human's life.

\section{METHOD}

In this study, the researchers used the qualitative research. In this study, the data can be taken from the interviews and observation to give the description of the data which were obtained from the people who live the society (Adedoyin, 2020; Cropley, 2019).

The researchers took the subjects from the society of Silau Malela of Bahsumbu village in Serdang Bedagai of North Sumatera Province in Indonesia. The location is nearby Tebing Tinggi because the location was the limitation between Serdang Bedagai and Tebing Tinggi. The people who lived there, were not too many, just a few people. The researchers observed the habits of community of Silau Malela. The society's incomes were obtained from the plantations and the farming by taking care of the cows. So they were closed to their animals and plantations in their daily life activities.

Firstly, the researchers did the observation to the location to see the society communication among their community members; secondly, the researchers did observation the relationship between their pets and farming pets; thirdly, the researchers interviewed the people who had the pets and plantations by giving some questions related to this study; fourthly, after getting the data from interview, then the data was filtered to enter this results and discussions. The researcher recordly, the people's expressions when they communicate to the pets and their plantation when they were in the location of field either guided the cows or gave the vitamin to their plantation. They did as they talked to human as usual. So it was going to create the relationship between the language and ecology in the Silau Malela people life.

\section{FINDINGS AND DISCUSSIONS}

From the obeservation, the researchers found a few important things in this study. The people who had a few pets or plantations, always gave the names of them as the human's names. They always gave the names of their dogs, such as: Rembo, Belang, Nero, Bleki, Dudut and their cows' names, such as: Bulek, Benggolo, Coklat, Mety, Montok, Babon, and many else. 
In this study, the researchers elaborated about the communications between the human and animals or other things. It was begun from the family members of the researchers. The real name of the people were not mentioned. When the researchers lived some days and observed that the owner of house has two dogs and a few cows.

The members of a house always gave the names such as Nero, Belang, and Dudut. There were three dogs who lived in the house. When one of grandchildren ( a boy) wanted to command the dogs to do something, he would call the names of the dogs. The boy always communicated to his dogs to help him to guide the cows who would be taken to the wide field. For example: he usually asked Nero to accompany him to go to the field to herd the cows. He said: " Nero, usir lembu yang jauh ke sana tuh. Then Nero (name of dog) ran to the one of cows to guide it back to the group while Nero was barking to the cow. After guiding the cow, Nero got back to the boy. Nero was waiting for the boys and the cows go far away from the bouse.

After all of cows were at the field and one of dominant cow has to be tied, the boy went back to home to take a rest and have lunch. Then the three dogs were waiting for him to feed them the food. When one of the dogs (Nero) were barking, the boy said “ wait a minute (bentar).jangan ribut kali (Don't make a noise). Setelah aku makan siang (After I had a lunch), aku kasih makan kau nanti (I will give your food).Diam! (Shut up). At that time, all od the dogs were quiet and it was nothing noise.

The researchers listened what the boy's expressions to the dogs and he mentioned one by one of the dogs by calling the names of dogs. All dogs wagged their dogs. It means that the dogs understood and did what the boy asked something. Nero, Belang, and Dudut were so quiet when the boy gave them the food. After eating lunch, the two dags, Nero and Belang sat to see the boy who was back to the field where the cows were placed. The dogs; Nero and Belang were waiting for the boy's instruction. When the boy said: ayo, Nero dan Belang (let's go, Nero and Belang), ikut atau gak dengan aku? (Do you want to follow me or not ). The dogs gave the response by wagging their tails, wagging the tails means that ya (yes), kami ikut (we follow). Then the dogs got together with the boy to guide the cows.

When the boy and the dogs were at the field where the cows were eating the grass, the researchers communicate to the cows that were far from their group, the boy said: woi.... balek sana ke lainnya (back to your group). Jangan jauh-jaub makan rumputnya (do not go far to eat the grass), nanti kau kesasar (you will get lost later). Nero dan Belang, kalian tuntun lembu itu agar lembu bisa bersatu dengan yang lainnya (Nero and Belang, guide the cows in order to get together others). So the dogs did what the boy commanded the statement, it means that the dogs understood it.

After that, the boy, the dogs and the cows went back home because the time is evening. The dogs were walking in front of the cows to see the situation and the cows were in the middle after the boy. The boy was just in the back to look around the cows if there was a cow which got lost or broke 
the plantations when they were walking across on the way. The boy was back, not guided the cows, but also he had to keep the cow in order to break the environment because other people would be angry with the boy if the cows ate or break their plantation. Sometimes, the boy was angry with the cows and he said: Benggolo, jangan kau makan daun pisang itu. Makan aja kerjamu. Then the cow that was mentioned the name, saw behind him (saw the boy) while Benggolo walked ahead quickly.

When the animals (the cows) got closed the cowshed, the cows ran anywhere to eat the grass that the boy put in the cowshed based on their position. Once, the boy used a wood to guide the cows so that the cows were afraid of him and went to the cowshed. Sometimes, the boy was angry and expressed the statement: Masuk ke kandang (enter into the cowshed), jangan lari kemana-mana (Do not go anywhere). Nanti ku tendang mau? (I would kick you later) When the cows heard the expression, they were not brave to go anywhere because they had undrstood that the boy was really angry. Then when it was at night, the dogs were hungry and came to the boy to ask the food. Nero, Belang, and Dudut came closer him. The boy understood that they were hungry and the boy also expressed the statement. Ntar ya, nanti ku buatkan makanan kalian (wait a minute, I would make your food).

In the next morning, the grandmother of the boy gave the food to her chicken, hen, and cock. The garnadmother said something; ayo (come here), kemari (come here), nah....nah.... makan jagung ini (this is...this is..... eat this corn). Nah.....nah..... kemana nih yang lainnya? (this is...this is..... where were others? The hen, cocks, and the chickens were coming closer to eat the food because they had heard the grandmother's sounds. In this event, there was the communication between the human and her pets when the huamn wanted to give the food to the animals. Even though, there was an eagle that got closer the chickens, the grandmother gave the signal in order to the chickens went far from the location to find out the safe place. Then when the grandmother (owner of chickens) was not at home, her daughter tried to give the food to the chickens, the chickens did not want to get close the food bacause the chickens did not know the strange sounds. So the daughter used her mother's clothes or dresses. The daughter said the same expressions as her mother usually did to the chickens. (ayo (come here), kemari (come here), nah....nah.... makan jagung ini (this is....this is.... eat this corn). Nah.....nah..... kemana nih yang lainnya? (this is ... this is..... where were others?). The chickens came closer because they saw that the clothes were so familiar.

After observing a house and the owners' attitudes and behaviours to their pets, the researchers observed other people's habits to their pets and plantations. It was the same thing. The old man had two cows, the names of cows were Bulat and Cantik. When the old man was barking the cows to get free at the wide field, he said something to the cows. Ayo......cepat Bulat dan Cantik....(lets go..... burry up Bulat and Cantik....). kita pergi ke sana agar kau bisa makan banyak nanti (we go to the wide field in order to eating the grass as much as you can). Jangan kalian injak atau kalian makan tanaman itu (Do not step on or you eat the 
plantations).. Kalau kalian makan, kau rasakan nanti (If you eat, you will feel it later). So when the cows were walking to the cowshed, the cows sometimes got closer other people who were also walking. The owner of cows gave the command: ha...jangan kau tanduk pula mereka. Ku pukul nanti ya kalau kamu tanduk orang yang sedang jalan itu.(ba....do not you horn them. I would bit you if you horn the people who were walking on the side position). Then the cow saw the owner while it sounds, boo..... the sounds of cow boo....means that it understood what the boss commanded to it. If the cow did not care its owner's commands, the owner would call its name and he would be angry with it and screamed its name so that the cow that was called its name, would know that the commands were for it.

There were a few people who lived there (Silau Malela of Bahsumbu) who always talked to their plantations especially when they gave the vitamins for the plantation. The people said: ini, ku berikan vitamin untuk batang dan buah ya agar batang kamu besar dan bisa menghasilkan buah yang banyak. (this, I gave the vitamins for your branches and fruits so that your branches were growing great and you could produce many fruits). Ayo..... kamu seraplah makanan vitamin ini. Aku berikan ini hanya untuk mu, ya cabe (come on..... you could absord this vitamin food. This was happened when they went to their plantation areas. After 30 until 40 days, the plantation had many small fruits which were so fresh.

The people had a cat, they always called the name of cat was manis and hitam. The reserachers also noticed to the people of Silau Malela who had a cat or two cats. They had same name to the cats and the cats were able to understand about the expressions of its owner. When the cat came to the owner or got closer the owner, the cats always sounded meong....meong. It was lunch time, the owner directly understood that the cats asked its lunch. So the owner said: kamu lapar ya, manis. Tunggu ya (you were bungry yeah, Manis. Wait a minute). Aku siapkan dulu makanan mu tetapi kamu sabar dulu (I would prepare your food, but you had to be patient). Sometimes, the cats were yawning, the cats went to find out the place to sleep and the owners also understood. Then the owners let it to sleep anywhere the cats were sleeping. If it was at night, the cats automatically went out of the house. The owner said: uda malam (it was late at night), kau tidur di luar ya karena kalan kamu di sini, kan ribut, meong....meong... minta kleuar rumah (you usually slept outdoors because you would make a noise here by your sounds, meong....meong...). After hearing the commands, the cats directly went out of the house. The unique happening was at the home, the cats and the dogs never fought or aquarrel each other as we knew commonly.

\section{CONCLUSIONS}

From the elaboration above, it can take the conclusions that language and ecology are so close relationship because ecology is related to the environment and language is related to human. Then both tpics are eolinguistics which considers the ecological aspects of the language spoken by speakers in a society. The people are so familiar to their environment 
especially with their pets and plantations. The people always give the name for their pets and plantations that they have. They often communicate to them in their daily activities so that they can understand each other. When the people express the statements to their pets, the pets also understand what their owners want to do something so that the pets can sound their voice as a signal that they know all.

\section{References}

Adedoyin, O. B. (2020). Qualitative Research Methods. Principles of Social Psychiatry: econd Edition, 77-87. https://doi.org/10.1002/9780470684214.ch7

Chen, S. (2016). Language and ecology: A content analysis of ecolinguistics as an emerging research field. Ampersand, 3, 108-116. https://doi.org/10.1016/j.amper. 2016.06.002

Cropley, A. (2019). Introduction to qualitative research methods. In $A$ research handbook for patient and public involvement researchers. https://doi.org/10. 7765/9781526136527.00012

Crowley, F., \& Bowern, C. (2010). An Introduction to Historical Linguistics: Fourth Edition (Fourth Edi). Oxford University Press. www.oup.com

Fill, A. F., \& Penz, H. (2018). The Routledge handbook of ecolinguistics. In A. Fill \& H. Penz (Eds.), The Routledge Handbook (First Edit). Routledge Taylor \& Francis Group. https://doi.org/10.4324/9781315687391

Fill, A., \& Muhlhausler, P. (2001). Ecolinguistics Reader: Language, Ecology and Environment. In Continum (First Edit). Continuum. http://books.google. be/books?id=cXnt7se75tMC

Garner, M. (2005). Language Ecology as Linguistic Theory. Kajian Linguistik Dan Sastra, 17(33), 91-101.

Jismulatif, J., \& Dahnilsyah, D. (2019). Language and Ecology in Ecolinguistics Perspective : A Case Study on Tunjuk Ajar Language in Riau, Indonesia. Journal of Physics: Conference Series, 1351(1). https://doi.org/10.1088/1742-6596/1351/1/012068

Muhlhausler, P. (2020). QUO VADIS ECOLINGUISTICS? Ecolinguistica: Revista Brasileira de Ecologia e Linguagem, 06(01), 5-23.

Simanjuntak, T. A. (2019). ECOLINGUISTIC “ WATER ” IN TOBA BATAK. Journal BASIS, 6(2), 209-214. http://ejournal.upbatam.ac.id/index.php/basis

Skutnabb, T., \& Kangas. (2011). Language Ecology. In J.-O. Ostman \& J. Verschueren (Eds.), John Benjamins Publisbing Company (Vol. 8, Issue 3, pp. 178-198). Benjamin Publishing Company. https://doi.org/10.1075/gest.8.3.02str

Steffensen, S. V., \& Fill, A. (2014). Ecolinguistics: The state of the art and future horizons. Language Sciences, 41(January), 6-25. https://doi.org/ 10.1016/j.langsci.2013.08.003

Stibbe, A. (2015). Ecolinguistics: Language, Ecology, and the Stories We Live By. Researchgate, May 2015. https://doi.org/10.4324/9780367855512

Suryati, N. M., Indrawati, N. L. K. M., \& Sukarini, N. W. (2018). DINAMIKA LEKSIKON KEPISANGAN DALAM BAHASA BALI: KAJIAN EKOLINGUISTIK (STUDI 
Lensa: Kajian Kebahasaan, Kesusastraan, dan Budaya

Vol. 11 No. 2, July-December 2021, Page.185-193

p-ISSN: 2086-6100

http://jurnal.unimus.ac.id/index.php/lensa

e-ISSN: 2503-328X

PENDAHULUAN). In K. E. Sukamto (Ed.), Prosiding kongres internasional masyarakat linguistik indonesia (kimli) 2018 (pp. 239-243). Masyarakat Lingiuistik Indonesia.

Yuniawan, T., Rokhman, F., Rustono, R., \& Mardikantoro, H. B. (2017). The Study of Critical Eco-Linguistic in Green Discourse: Prospective Eco-Linguistic Analysis. Jurnal Humaniora, 29(3), 291-300. https://doi.org/10.22146/jh.v29i3.27441 